\title{
GCU
}

Glasgow Caledonian

University

University for the Common Good

\section{Comparing energy efficiency labelling systems in the EU and Brazil: implications, challenges, barriers and opportunities}

Wong, Ing Liang; Krüger, Eduardo

Published in:

Energy Policy

DOI:

10.1016/j.enpol.2017.07.005

Publication date:

2017

Document Version

Author accepted manuscript

Link to publication in ResearchOnline

Citation for published version (Harvard):

Wong, IL \& Krüger, E 2017, 'Comparing energy efficiency labelling systems in the EU and Brazil: implications, challenges, barriers and opportunities', Energy Policy, vol. 109, pp. 310-323.

https://doi.org/10.1016/j.enpol.2017.07.005

\section{General rights}

Copyright and moral rights for the publications made accessible in the public portal are retained by the authors and/or other copyright owners and it is a condition of accessing publications that users recognise and abide by the legal requirements associated with these rights.

Take down policy

If you believe that this document breaches copyright please view our takedown policy at https://edshare.gcu.ac.uk/id/eprint/5179 for details of how to contact us. 


\title{
COMPARING ENERGY EFFICIENCY LABELLING SYSTEMS IN THE EU AND
} BRAZIL: IMPLICATIONS, CHALLENGES, BARRIERS AND OPPORTUNITIES

\author{
Ing Liang Wong ${ }^{1}$, Eduardo Krüger ${ }^{2 *}$ \\ ${ }^{1}$ School of Engineering and Built Environment, Glasgow Caledonian University, 70 Cowcaddens Road, \\ Glasgow, G4 OBA, UK \\ ${ }^{2}$ Departamento de Construção Civil, Universidade Tecnológica Federal do Paraná - UTFPR, Campus \\ Curitiba - Sede Ecoville, Rua Deputado Heitor Alencar Furtado, 4900, 81280-340 Curitiba-PR, Brazil
}

\begin{abstract}
In the last 30 years, voluntary and mandatory environmental or energy certification schemes have been introduced in the building sector in most developed countries. During the last decade, in Brazil, the document Energy Efficiency Rating Technical Quality Regulations for Commercial, Service and Public Buildings (RTQ-C) was introduced to classify buildings according to their energy efficiency level. This paper aims to assess how Brazilian RTQ-C could learn from the European Union (EU)'s experience of implementing the Directive 2010/31/EU. The implementation of the RTQ-C in Brazil has been examined and compared with the EU's Directive. Technical, economic and social issues as well as barriers and challenges behind the initial stage of the Directive 2010/31/EU implementation were examined. The difficulties and weaknesses of the calculation methodology, scope and labelling of the Brazilian RTQ-C regulations, and potential areas that require further research have been identified and summarised. In order to increase the impact of RTQ-C regulations, improvements to the existing calculation methodology and tools, provision of numerous supporting measures, such as an increase in training, education, public awareness and incentives, and enforcement through building regulations or standards are essential. The valuable experience from the EU's implementation of the Directive could be used to guide the development of energy policies and certification regulations in Brazil.
\end{abstract}

Keywords: energy rating systems, energy efficiency labelling, EPBD, RTQ

\section{Introduction}

Buildings as the main contributors to carbon emissions, account for up to one sixth of the emissions in the European Union (EU) (European Commission, 2011) or one third in the United States (US) (Department of Energy, 2012). In order to reduce carbon emissions from the building sector, voluntary and mandatory environmental or energy certification schemes have been gradually introduced in the real estate sector in

\footnotetext{
${ }^{*}$ Corresponding author

Email addresses: IngLiang.Wong@gcu.ac.uk, xijiayu@hotmail.com (Ing Liang Wong); ekruger@utfpr.edu.br (Eduardo Krüger)
} 
most developed countries since early 1990s, which reflects the growing interest in reducing carbon emissions from the real estate stock. Prior to these schemes, energy efficiency labelling has already been implemented in household appliances in more than 50 countries globally. Such energy efficiency labels provide accurate energy consumption information for the appliances and are useful for consumers when making purchase decisions (Harrington and Damnics, 2004). Early research (Gilmer, 1989; Dinan and Miranowski, 1989) showed positive impacts of energy labels on the improvement of energy efficiency in residential buildings. A brief review of recent approaches to energy rating shows that, strategies for defining energy efficiency in buildings are essential for successful energy rating (Olofsson et al., 2004). The historic development of energy certification schemes in buildings, including the definition and scope of benchmarking process, energy rating and labelling was reviewed. Guidance was also proposed for implementing building energy certification (Perez-Lombard et al., 2009).

Various governments around the world have initiated energy rating systems to measure energy performance in both residential dwellings and commercial buildings (Brounen and Kok, 2011). The use of a range of voluntary and mandatory energy rating standards in up to 81 countries across the EU, North and South America, Australia and Asia have been gathered, critically reviewed and compared (Janda, 2009; Rajagopalan and Leung, 2012). The 'Energy Star' programme is a notable example of energy rating systems used in the US in buildings and also in domestic appliances (Olofsson et al., 2004; Miguez et al., 2006; Rajagopalan and Leung, 2012). Similarly, the 'Energy Smart' programme (Singapore), the 'Energy Smart' certification (Japan), the 'Energy Conservation Building Code' (India), the 'National Australian Built Environmental Ratings Scheme (NABERS)' and the 'Nationwide House Energy Rating Scheme (NatHERS)' (both in Australia) are energy rating systems used in other parts of the world (Rajagopalan and Leung, 2012). Fossati et al. (2016) present an overview of energy rating systems and regulations in the world, including the Brazilian energy efficiency and labelling scheme. Based on the actual energy performance for a given building for the previous twelve months, NABERS was firstly introduced in 1999 on a voluntary basis and has recently become mandatory for commercial buildings of more than $2,000 \mathrm{~m}^{2}$, which cover more than $70 \%$ of floor area of qualified office buildings (Energy World, 2017). The success of NABERS in Australia has been driven by the use of different ratings for base buildings and tenants (Bannister, 2013).

In Europe, the efforts to classify the energy performance of the real estate sector actually originate back to Article 2 of Directive 93/76/EEC, with the purpose to limit carbon dioxide emissions (EC, 1993; PerezLombard et al., 2009). The Directive also required a collective effort by all Member States (MS) to limit carbon dioxide emissions and to promote the rational use of energy. Despite the non-mandatory 
implementation of energy certification in buildings under this Directive, Denmark became the first country to implement energy performance rating in buildings back in 1997, making it a reference point for other European countries (Miguez et al., 2006; Jensen et al., 2016). The need for a new legislation in the early 2000s led the European Commission (EC) to introduce Directive 2002/91/EC on the energy performance of buildings (EC, 2002), which made energy performance disclosure mandatory in all MS (Perez-Lombard et al., 2009). The Article 7 of the Directive makes mandatory the introduction of comparable Energy Performance Certificates (EPCs) across the EU. A typical EPC includes reference values, such as current legal standards and benchmarks for consumers to compare and assess the energy performance of a building (Fabbri et al., 2011). Even though Directive 2002/91/EC came into force in January 2004, it has only been formally implemented in January 2006 due to the time needed for every MS to transpose it into their national legislation. An additional period of three years was given for MS to fully adhere to the certification procedures due to the lack of qualified and/ or accredited experts (Hernandez et al., 2008; Brounen and Kok, 2011). A study was carried out showing differences and similarities among energy rating systems implemented in MS (Miguez et al., 2006). In 2010, the recast, Directive 2010/31/EU (EC, 2010) has expanded the scope of the Directive. It was required that EPC and its energy saving recommendations have to be included in all advertisements for selling or renting properties (Brounen and Kok, 2011; EC, 2013). All buildings at the point of completion, sale or rent should possess EPCs, which give information about their energy performance and are valid for ten years (Fuerst et al., 2015). This is followed by the introduction of the Energy Efficiency Directive (EC, 2012) in 2012, which requires more drastic measures to promote energy efficient buildings, including long-term national building renovation strategies in the MS.

Brazil, along with other developing countries, is facing the issue of growing energy consumption. Official figures show that buildings accounted for $50 \%$ of the total electricity energy consumption in Brazil in 2014 (MME, 2015). Much of the electricity wasted due to energy inefficiency in commercial and public buildings reported are related to building envelope, air conditioning systems, lighting systems and hot water supply (Lamberts, 1996). During the last decade (2005-2014), energy consumption in the commercial and public sectors increased by approximately $40 \%$, whereas consumption in the service sector increased by around $60 \%$ (MME, 2015). In 2001, the Brazilian government took the initiative to introduce the Law No 10.295 (Brazil, 2001a), which was published under Code-Decree 4.059 (Brazil, 2001b), as a result of Energy Efficiency Act on the National Energy Conservation and Use Policy in Brazil. The Law further strengthened Brazil's National Electricity Conservation Programme (PROCEL), which regulates the efficiency of appliances in Brazil and has been promoting several actions towards electric energy conservation since the 
1980s (Nogueira et al., 2015). The PROCEL Edifica Programme was launched in 2003 by the Brazilian government through the Action Plan for Energy Efficiency in Buildings to reduce the electricity consumption in Brazilian buildings. It defines procedures required for Brazilian buildings, covering building certification, regulations and legislation on energy efficiency. Subsequently, the Federal Regulation for Voluntary Labelling of Energy Efficiency Levels in Commercial, Public and Service Buildings was developed and approved in 2006 (Lamberts et al., 2006; 2007; Pollis, 2013; Borgstein and Lamberts, 2014). Under the regulation, voluntary requirements for energy efficiency labelling were introduced to classify buildings according to their energy efficiency level thereby limiting and controlling energy consumption in buildings (Lamberts et al., 2006). Lamberts and colleagues from the Federal University of Santa Catarina, Brazil, have been pioneering the work in developing a technical base for the regulation since 2004 (Lamberts et al., 2007). In February 2009, the Energy Efficiency Rating - Technical Quality Regulations for Commercial, Service and Public Buildings (RTQ-C) and its supplementary documents (MME, 2009a; 2009b; 2009c; 2009d) were introduced, approved and published by the Brazilian Federal Government. Lately, Fossati et al. (2016) conducted a detailed review on energy efficiency rating systems for Brazilian buildings; whilst Lopes et al. (2016) compared the Brazilian system with both the US and Portugal systems and highlighted how the Brazilian system can be improved in methodology adopted and scope of calculation.

The aim of this research is to assess how Brazilian RTQ-C could learn from the EU's experience of implementing the Directive 2010/31/EU using a mixture of literature review, site visit, and detailed analysis of the RTQ-C calculation methodology. A thorough literature review has been conducted, whilst RTQ-C calculation methodology has been studied, analysed in detail and compared with the EU's Directive 2010/31/EU. During the initial stages of the research, visits took place and inside information was gathered as regards a number of RTQ-C certified Brazilian buildings, including the first RTQ-C certified building in Brazil (a bank branch located in Curitiba, State of Paraná). This was followed by detailed discussions and meetings held with Brazilian experts to understand the development and calculation method behind the RTQC regulation.

The paper presents the current state of the implementation of the Brazilian energy efficiency rating scheme. Barriers and opportunities are anticipated based on preceding introduction of similar rating systems in EU MS and more specifically in the United Kingdom (UK). Even though there are recognizable differences in context between realities analysed (GDP, concern for environment, degree of industrialization among others), globalization trends will play a role in the pressure needed for more efficient buildings. Indeed, presently in Brazil, many buildings are certified according to non-indigenous standards such as the North-American 
Leadership in Energy \& Environmental Design (LEED) Certification with a rising trend (GBC 2017). Along with LEED certificates, which started to be issued from 2004, an adaptation of the French certification NF Bâtiments Tertiaires - Démarche (HQETM) was made for the Brazilian context within a collaboration scheme started in 2007. The 'AQUA' ('Alta Qualidade Ambiental') rating scheme is the adapted version of HQETM. It is recognized that adaptations of existing, foreign methods may prove insufficient to cope with context-related issues (Cole 2005); thus, the development of a national certification and the anticipation of problems arising from its full implementation are of utmost importance.

Figure 1 describes the structure of the paper and scope of this research. We start off by describing the Brazilian RTQ rating system (components, calculation methods, certification, and the existing difficulties as regards the simplified method). EU experience is briefly commented and the UK system is more thoroughly detailed. From the EU/UK experience, implications of the full implementation of Energy Performance of Buildings Directives (EPBD) are reviewed thereby stressing the importance of having set standards for energy efficient buildings in terms of technical, economic and social aspects. Based on the key finding from the literature review, we list potential barriers and challenges to the implementation of energy efficiency labelling regulations in Brazil.

-Figure 1-

\section{Comparison between energy efficiency labelling systems in Brazil and in the UK}

\subsection{Brazil}

There are three main categories of assessment in the RTQ-C regulation: lighting system, expressed by the internal Lighting Power Density (LPD), air conditioning system (AC), and building envelope (ENV), which can be calculated using prescriptive or simulation methods. In order to obtain the final classification of a building, each requirement must be evaluated separately according to the specific assessment procedures (Lamberts et al., 2007). The final classification can be calculated taking into consideration a weighting distribution of 30\%, 40\% and 30\% for LPD, AC and ENV, respectively (Lamberts et al., 2007; Lopes et al., 2011a). The total score (PT) can be used to define the final classification of the building (A to E), which vary according to Table 1.

-Table 1-

2.1.1 Prescriptive method 
The prescriptive method uses the Simplified Method to calculate the energy performance of the building envelope and to assess the energy efficiency level of lighting and air conditioning systems (Melo et al., 2014). Equations were developed from simulations analyses of energy performance of building prototypes representing the most common characteristics of commercial buildings, based on actual sample buildings in 5 Brazilian cities (Lamberts et al., 2007; Carlo and Lamberts, 2008). The envelope analysis takes into account geometric attributes of the building (shape factors, shading elements, façade orientations etc.) and characteristics and properties of materials for wall and roof designs, according to the Brazilian bioclimatic zone where the building is located. Parameters related to window openings and external shading are critically analysed (Melo et al., 2014). A Consumption Indicator (CI) is calculated according to the Bioclimatic Zone corresponding to the building location and then compared to a numerical scale (Lamberts et al., 2007). The assessment of the air conditioning system (AC) depends on the efficiency level of the equipment, which is evaluated or classified by the National Institute of Metrology (INMETRO) or in accordance to ASHRAE 90.1 requirements (Lamberts et al., 2007; Carlo and Lamberts, 2008; Melo et al., 2014). For the lighting system assessment, the maximum allowance of internal Lighting Power Density (LPD), expressed as W/m² units, is determined and compared to a reference table based on the building area method according to Table 4.1 of the Brazilian regulation (Melo et al., 2014). In order to obtain rating A, there are some mandatory requirements or pre-requisites that must be complied in addition to the calculations using the prescriptive method (Lamberts et al., 2007; Lopes et al., 2011a).

\subsubsection{Simulation method}

Alternative to the prescriptive method, the simulation method can be used to compare the results to a similar building that complies with the initial prescriptive method (Lamberts et al., 2007). In this case, the simulation compares the performance of the proposed building design (actual building) with a reference building. The reference building must be modelled according to the Brazilian regulation prerequisites and for the intended efficiency level. Energy performance simulations for both the proposed and the reference buildings should be carried out using a similar simulation program, weather data, building orientation and building specifications (Lopes et al., 2011a). When the simulated final energy consumption of the actual building is compared to the results of reference building, the energy consumption of the actual building should be equal or lower than the energy consumption of the reference building in order to comply with the intended level of requirements (Lamberts et al., 2007; Melo et al., 2014). In certain scenarios, it is compulsory to use the simulation method, e.g. when natural lighting (percentage of skylight higher than 5\%) and natural ventilation are dominant in the building. Even though there is no prescription of a standard simulation package to be used, it should meet 
certain criteria, such as providing hourly building energy demand as main simulation output data. The computational tool S3E, which uses EnergyPlus as simulation software and Domus PROCEL Edifica are two energy simulation programs, which are commonly used in the simulation method (Lopes et al., 2011a; 2011b).

\subsubsection{Certification}

The certification process has been divided into two phases, where two types of certificates can be issued for design and completion, respectively. Figure 2 shows a typical energy efficiency performance certificate for the design stage, issued using the prescriptive and the simulation methods. Initial certificates can be issued during the design phase with relevant documentation to prove that a given efficiency level has been met. Once the construction of building is completed, auditing can be carried out by Accredited Inspection Bodies (AIB) to confirm that all design requirements have been implemented accordingly. A completion certificate can be then issued for display in the building. There are currently only four Building Energy Efficiency AIBs registered in Brazil (INMETRO, 2017). To make matters worse, according to a recent review paper by Lopes et al. (2016), there are not enough professionals in the area trained to certify buildings and there is at the moment just one entity allowed to label buildings in terms of energy efficiency.

-Figure 2-

2.1.4 Methodologies available and limitations of the RTQ's Simplified approach

Over the last 30 years, different approaches and methodologies have been developed to evaluate the energy performance of buildings. Borgstein et al. (2016) provide a comprehensive review of all available methods for analyzing, classifying, benchmarking, rating and evaluating energy performance in non-domestic buildings. One of the earliest methods used is a simple index, which is also known under the generic term of Home Energy Rating Systems (HERS). It can be classified into three main categories: the points system which attributes performance scores to envelope or existing HVAC features; the performance system in terms of cost or consumption; and the awareness system, according to how the energy performance was evaluated in buildings (Zmeureanu et al., 1999). HERS is usually a computer-based simulation method, whose performance can be further improved when actual data from utility bills can be used to validate its predictive ability and calibrate the rating system (Stein and Meier, 2000). Zmeureanu et al. (1999) developed a novel energy rating system, which combined the features of the performance and awareness systems in existing houses in Montreal, Canada. It was concluded that the owner's awareness could be increased by the 
presentation of the actual energy performance compared with that of reference dwellings and by consideration of the potential savings from renovation/retrofit measures and changes in user's habits.

Simplified models can be used for predicting energy performance in buildings due to features such as less complexity compared to energy simulation models, ease of use and speed of calculation (Kramer et al., 2012; Borgstein et al., 2016). In Brazil, the original Simplified Method for determining energy efficiency levels as proposed in the Brazilian building energy efficiency regulation is developed based on a multiple linear regression approach. However, the ability of the Simplified Method for determining energy efficiency levels was investigated by Van der Knaap (2011) against building performance simulations, showing inaccurate estimates for residential buildings. Results indicated that the Simplified Method embedded in the RTQ-R (in this case, for residential buildings) underestimates energy efficiency of natural ventilated buildings and overestimates energy efficiency of air-conditioned buildings.

The accuracy of the proposed Simplified Method by the Brazilian building energy efficiency regulation for commercial buildings (RTQ-C) was assessed by Melo et al. (2011). The results were compared with the Building Energy Simulation Test (BESTEST), which show the Simplified Method underestimated the energy efficiency level of four different typologies of commercial buildings when compared to building energy simulations (Melo et al., 2011; 2012). Subsequently, a more accurate method was developed using an artificial neural network (ANN) approach (Melo et al., 2013). The ANN Model was tested for 16 different building typologies against energy simulations with EnergyPlus showing a superior predictive performance relative to the current Simplified Method. Melo et al. (2013) claim that such results can have a "profound impact as artificial neural network may be applied in the future in the Brazilian regulation"; and that reflects the current trend in the present revision of the fundamentals behind the Brazilian building energy efficiency regulations for commercial and residential buildings.

Since the publication of the RTQ-C in Brazil in 2009, the compliance is initially voluntary but will be expected to become mandatory progressively (Lamberts et al., 2007; Batista et al., 2011). Lamberts and colleagues have been actively involved in the development of methodologies for achieving compliance using both prescriptive and simulation methods based on various building examples (Lamberts et al., 2006; 2007; Lopes et al., 2011a; 2011b). The concept of energy efficient building designs in the Brazilian regulation was also discussed and explored at an early stage (Meier et al., 2002). According to the current building energy efficiency regulation, buildings can be classified into five levels according to their energy efficiency level: from "A" (most efficient) to "E" (least efficient) (Melo et al., 2012). The certification can be carried out using either one of two methods: prescriptive or simulation method. The prescriptive method is based on a set 
of prescriptive rules combined with the results of the Simplified Method for calculation of energy performance of building envelopes introduced by RTQ-C; whilst the simulation method uses hourly building energy simulation results (Melo et al., 2012; 2014). The accuracy of the assessment method for Brazilian energy efficiency labelling regulations has been rigorously tested in the last ten years. Several researchers have tested the method or validated the models presented in the Brazilian regulation with ANSI/ ASHRAE Standard 90.1 (Melo et al., 2014), BESTEST (Melo et al., 2011; 2012), EnergyPlus or DAYSIM simulations (Fernandes and Labaki, 2012; Reckes et al., 2016; Melo et al., 2016). Parametric studies involving load density of equipment, shape factor, envelope thermal transmittance were carried out as well (Brandalise et al., 2016). In addition, supplementary software such as DIALux lighting design software was used to calculate the lighting electricity demand to ensure the building meet the A rating of the Brazilian energy efficiency regulation (Piai et al., 2015).

\subsection{European Union - United Kingdom}

In the EU, Directive 2010/31/EU ensures that EPCs are issued for buildings in all MS when constructed, sold or rented out. The Directive also places an obligation to the real estate sector, where EPC must be included in the advertisements to sell or rent the buildings and displayed in frequently visited public buildings. The purpose of publishing EPC in advertisements is to create awareness of building energy performance among potential buyers and tenants. Two main types of energy rating used in the EU are asset (calculated) and operational (measured) energy rating. Perez-Lombard et al. (2009), who reviewed and analysed the origin and the historic development of energy certification schemes for buildings, suggested that operational rating should be used for energy certification for existing buildings, whilst asset rating should be used for new buildings. The methodology adopted to develop energy benchmarks and rating systems in the EU, taking into consideration both calculated and measured energy rating is presented in detail by Hernandez et al. (2008). For example, the EPC in the UK shows the asset rating of the building; whilst Display Energy Certificates (DEC) displayed in public buildings show operational energy rating of the buildings for the last twelve months. Despite the fact that both asset and operational ratings use $\mathrm{CO}_{2}$ emissions as numeric indicator to reflect energy consumption in certified buildings, asset rating shows only energy rating based on the building's design features and does not depend on building occupancy, tenant behaviour or operating schedule. Operational rating however, is based on day-to-day operations of a building, which measures the amount of energy consumed during the occupation of the building over a period of twelve months, based on meter readings. Operational rating is affected by operating schedule and occupant behaviour. According to previous studies, asset rating shows only the theoretical energy performance of buildings based on 
standardised data and assumptions that rarely, if ever, reflect true energy performance which can solely captured by operational rating (Healy, 2011; Strong, 2009). Both asset and operational ratings have been developed based on different performance benchmarks identified for representing different categories of building under a number of standardised conditions (DCLG, 2008). The reference values (benchmarks) for asset rating have been taken from regulatory standards; whilst operational rating uses the existing building stock as benchmark.

Most MS have developed software or simplified calculation tools for building energy rating calculation. However, most of these software or tools are country-specific and their applicability is limited to the country where they have been developed (Rajagopalan and Leung, 2012). Even though the criteria behind the energy rating calculations may differ from one country to another, depending on the climatic conditions, priority and methodology in each MS, Directive 2010/31/EU requires the energy performance data of a given building to be displayed on the certificate. Stead (2009) emphasizes the need for the rating tool to give more weight distribution to the reuse of existing building fabric, embodied energy conservation and reduction of waste deposited to landfill. Evaluation of whether or not a given building is more energy efficient than another can be complex if the activities in these buildings or the climatic data/ parameters are not the same (Olofsson et al., 2004). In the UK, the energy performance of non-domestic buildings is calculated using a methodology called Simplified Building Energy Model (SBEM). A calculation tool, Interface for SBEM (iSBEM), has been developed for the energy performance calculation and EPC production. Figure 3 shows examples of EPC issued in England and Wales, Scotland and Northern Ireland for non-domestic buildings using SBEM. Table 2 shows the summary of assessment criteria for both RTQ-C and SBEM methodologies.

-Figure 3-

-Table 2-

\section{Implications of energy efficiency labelling regulations}

In this paper, official reports and publications related to the implementation of Energy Performance of Buildings Directives (EPBD) in the EU/UK have been critically reviewed. The implications of implementing the EPBD requirements have been observed and analyzed. Evidence from various authors shows that the implementation of the EPBD has not only contributed to positive effects to an overall reduction of building energy consumption in the EU/UK, but also that it substantially contributed to a better understanding of the challenges and the pros and cons of various strategies to implement the EPBD requirements (EU, 2011; 
2015). Technical, economic and social implications for implementing the EPBD requirements can be pointed out.

\subsection{Technical implication}

The EC, through the EPBD requirements, has required national adoption and implementation of this Directive at the national level in all MS. The Directive has been transposed into national law and implemented through national regulations and a fine of up to EUR 5000 can be levied for non-compliance with the Directive (European Communities, 2006). Since the implementation, most countries have set their own specific targets such as minimum requirements for U-values of building fabric and minimum energy demands for buildings. Figure 4 shows the summary of U-values for building fabric as required by the existing and previous regulations in the EU countries. The figures demonstrate some limited adjustments over the years in terms of recommended U-values as a result of the implementation of the EPBD requirements in these countries, which is more evidently noticed in the cases of Greece and Portugal. It is also noticed that nonmatching U-values are given for building elements for the many locations: while opaque elements have less variations, transparent building elements (windows) have great fluctuations in terms of prescribed U-values with warmer locations having higher U-values. The general conditions for the Directives to be effective in controlling and limiting the energy consumption in the building sector are analysed (Casals, 2006). EU (2015) reveals a reduction in building energy consumption of up to $60 \%$ in the building sector in the EU, as a result of tightening of national regulations in EU countries. As shown in Table 3, it is clear that the energy efficient labelling regulations can have positive effects on energy performance of the building stock. In the existing Brazilian energy efficiency labelling regulations, U-values required for building envelope are consistent with the latest Brazilian Standard (ABNT, 2013a; 2013b). For example, in Bioclimatic Zones 1 and 2, U-values for external wall and roof of residential buildings should not exceed 2.5 and $2.3 \mathrm{~W} / \mathrm{m}^{2} \mathrm{~K}$, respectively. Compared with the EU standard, the importance of the U-values is significantly lower in warm climates (such as the mostly tropical Brazil) than in cold climates (such as in the majority of EU countries), where heating loads dominate. This can be evidenced in RTQ-C, where the recommendations for window shading elements and the use of reflective surfaces, which may have significantly greater impacts than U-values in tropical conditions, are discussed in detail.

-Figure 4-

-Table 3-

3.2 Economic implication 
It is difficult to quantify or calculate the financial advantages of commercial buildings in term of sales price premium as most commercial buildings are unique and thus, difficult to compare. Previous studies have mainly focused on residential buildings in the economic analysis. Studies confirmed that properties with higher energy efficiency rating can command a price premium, which acts as an economic incentive for property developers or owners to innovate or incur any additional costs associated with improved energy performance (Fuerst et al., 2016). A study conducted in 2008 on 10,000 properties found an effective rental premium of $6 \%$ and a selling premium of $16 \%$ for green office buildings (Eichholtz et al., 2009). The investigation on the price effect of mandatory energy labelling in Australian residential real estate market in 2006 found an estimated premium of approximately 2\% for every increase of 0.5 in Energy Efficiency Rating (ranges from 0 to 5) (Australian Bureau of Statistic, 2008); whilst in California (United States), a premium of 9\% has been reported for "energy efficient" residential buildings (Kahn and Kok, 2012). A statistical examination of Danish data from 2007 to 2012 on property sales prices and energy performance ratings showed that energy performance ratings had an impact on property sales prices (Jensen et al., 2016). Research also shows that properties rated with indicators of high energy efficiency were the easiest properties to sell in Denmark (Klejsgård Hansen, 2011). Elsewhere in the EU, a 2.2 to $10.2 \%$ price premium can be found for buildings in the top three energy ratings (rated $\mathrm{C}$ or better), compared to buildings rated D or worse in the Netherlands (EU, 2011; Brounen and Kok, 2011; Kok and Jennen, 2012) having no effect on the speed of sale. In Germany, a $1 \%$ increase in energy efficiency can produce a $0.45 \%$ increase in the market value of properties (Cajias and Piazolo, 2013). In Ireland, for every one point decline in energy efficiency rating measured on a 15 -point scale, a $1.3 \%$ reduction in the price of properties has been reported (Hyland et al., 2013). Approximately $60 \%$ of the response in an opinion survey said energy labels would have a positive effect on the market value in Poland (EU, 2011) and a report on the effect of EPC rating on property prices in different European countries, revealed positive increase in rents and sale prices in most European countries for an increase in EPC rating, with the highest increase of 8\% reported in Austria (EC, 2013).

In the UK, studies conducted by Fuerst and colleagues recently show a positive relationship between the energy efficiency rating of a dwelling and the transaction price per square meter in England, where a $1 \%$ increase in the energy efficiency score can produce a $0.1 \%$ increase in predicted dwelling price (Fuerst et al., 2015). Based on a sample of approximately 192,000 transactions on residential prices in Wales, significant positive price premiums are estimated for dwellings in EPC bands A/B (12.8\%) and C (3.5\%) compared to houses in band D; while for dwellings in band $\mathrm{E}(-3.6 \%)$ and $\mathrm{F}(-6.5 \%)$ there are statistically significant discounts, meaning that such buildings lose their added value due to low energy efficiency rating (Fuerst et 
al., 2016). However, there was no significant effect of EPC rating on appraised market rent or market value for the UK commercial properties studied in 2010 (Fuerst and McAllister, 2011). Most of the studies on the effect of energy efficiency labelling on building prices have used Hedonic Regression Method (Rosen, 1974) and a large sample of repeat sale transactions (Fuerst et al., 2015). The added value due to the improved energy performance of a building as a result of energy efficiency measures can also be taken into consideration in addition to potential savings to energy costs (Popescu et al., 2012). Figure 5 shows the total cumulative numbers of EPCs issued in selected European countries as of a particular year. Significant increase in the numbers of certificates issued can be observed in most countries due to the compulsory certification requirement in both domestic and non-domestic buildings.

-Figure 5-

-Table 4-

The cost of certification is one of the key issues for achieving widespread acceptance of the energy certification schemes (EU, 2011). During the initial implementation of the EPBD requirement in the EU, cost of certification has become an issue and cost structure was therefore proposed to identify the factors that affect costs. In the EU, the costs for issuing certificates are determined by the market in most countries; while in other countries, such as, Spain, Portugal and Malta, fixed prices (e.g. registration fees) have been added to the costs of the certificates. In most cases, certificates are normally charged to reflect the amount of necessary works or tasks carried out during certification process. The difference between certification costs for non-residential and large buildings are more significant in most countries, for example of up to EUR 20,000 per certificate, due to the size and complexity of these buildings. In some MS, costs of certification for non-residential buildings are in the range of 1 to 2 EUR per $\mathrm{m}^{2}$. For a typical single family house, a certificate costs an average of not more than EUR 300 in $85 \%$ of the MS in the EU (EU, 2015). Factors that affect the cost of certification should be identified in order to help the practical implementation of the certification, such as, number of expert available, types of buildings, and complexity of the certification methods. Apart from the cost of certification, quality assurance process which is essential to certification scheme contribute to the additional costs of certification (Santos and Wittchen, 2011; EU, 2011). Table 5 summarises the average certification costs for both residential and non-residential buildings in the EU. It was concluded that, the costs of certifying domestic buildings fall into a wide range in most countries; while the average costs of non-domestic building certification are difficult to estimate due to the complexity and size of the buildings. In the UK, the lower cost of certification for the existing domestic buildings was mainly due to the use of a 'simplified' version of the energy calculation tool, Reduced data Standard Assessment Procedure 
(RdSAP). The EPCs produced using RdSAP for existing domestic buildings are not sufficiently accurate as the EPC information and are therefore essentially an estimate based on assessors' visual inspection rather than the results of an in-depth energy audit of the entire property. There has been a concern of quality and reliability of the certificates issued for the UK domestic properties.

-Table 5-

\subsection{Social implication}

Apart from reductions in energy demand and resulting increases in property value, energy certificates can also bring about social benefits and improvements in quality of life. In order to realize the social impacts and benefits of energy labelling systems, it is essential for the public to know how to interpret and understand the information behind energy certificates. As energy certification is introduced as a market-based mechanism designed to inform consumers about the environmental or energy performance of buildings, the information provided on the certificates can positively affect consumer behaviour (Fuerst et al., 2016). For example, with increasing awareness in building energy efficiency consumers can opt for more energy efficient building strategies such as employing double or triple glazing and improving wall insulation, which not only contribute to better energy ratings, but also reduce noise pollution indoors and increase security (Fuerst et al., 2016). Furthermore, strengthening of building legislations that prohibit the leasing of dwellings below a minimum energy efficiency rating (Fuerst et al., 2016) may help improving the quality and energy efficiency of the building stock.

Studies show that energy certification can also positively affect the decision making process of practitioners involved in building design, depending on the financial capacity of developer and on the ability of building owners or stakeholders to conceptualize life cycle cost savings (Wong et al., 2015). Studies show that the presentation of the certificates should be eye-catching and clearly display relevant information as regards building performance such as energy performance levels, preferably using expressive graphical representation (e.g. stepped labels or continuous coloured band strips). For a certificate to become more effective, additional information such as recommendations on how to improve energy efficiency in buildings and what could be achieved when the recommended actions are carried out should be clearly shown. The certificates must be dated and the classification scale updated every five years to reflect future tightening of the building energy requirements (EU, 2011).

Finally, strategies toward energy efficiency will save energy normally generated from non-renewable sources, in many cases based on combustion of fossil fuels, which will elicit externalities such as harm to 
human health, climate change, and constraints on the foreign policy objectives of energy-importing countries (Allcott and Greenstone, 2012). Even Brazil, with a great part of its primary energy supply coming from hydroelectric plants, has been showing a slow but gradual trend toward non-renewables: between 2005 and 2014 , there has been an increase of just over 5\% in domestic energy supply coming from non-renewable energy sources. In respect of electricity generation, the relative percent drop of hydraulics in terms of its participation in the total generation, for the last five years (2011-2015), was around 20\% (EPE, 2016). In developing countries, improved energy efficiency is also important for achieving economic and social goals, including improved access to energy services, eradicating poverty, improving environmental sustainability, and economic development (Ryan and Campbell, 2012).

\section{Barriers and challenges to the implementation of energy efficiency labelling regulations in Brazil}

When discussing barriers to the implementation of energy efficiency regulations, a first notion to be considered refers to what is termed the 'energy-efficiency gap' which is an attempt to explain the "paradox of gradual diffusion of apparently cost-effective energy efficient technologies" (Jaffe and Stavins, 1994). Jaffe and Stavins (1994) see market barriers as explanation for such anomaly and Allouhi et al. (2015) refer political issues as primary barriers in the building sector, particularly in the developing world, where governments are mostly concerned on short-term issues, not implementation of energy-efficiency regulations that requires the involvement of several actors, policymakers and stakeholders. As highlighted by Chai and Yeo (2012), the implementation of energy efficiency regulations is country- or region-specific. Even different approaches have been adopted in the design of each MS's national regulatory framework in the EU, with regard to aspects, such as policymakers and stakeholders involved in energy regulations, building regulations and enforcement models, contextual characteristics, and maturity of the country in the implementation of energy efficiency measures (Annunziata et al., 2013). The diversity of challenges faced by 27 MS towards energy efficiency certification and its full implementation was examined by Andaloro et al. (2010). With the compulsory implementation of EPBD from 2006 onwards, the amount of time and the extent to which the Directive has been implemented by the MS were evaluated. Despite the Directive being implemented within a fairly close timespan in all MS, progress is very diverse due to differing conditions and needs of each MS.

A mixture of standards and incentives is the main policy mechanism for addressing such issues (Gillingham and Palmer, 2014). Subsidies are the most common way to promote energy-efficient products. Standards such as building codes have mixed results on energy consumption, ranging from no effect on energy demand 
to discrete decreases in electricity consumption (Gillingham and Palmer, 2014). The extent of such decreases may be directly related to the rigorousness of the building codes. With regards to the scales used in the energy efficiency rating, Andaloro et al. (2010) praise the MS, which have made their rating system more detailed by subdividing the classes to such as A- and A+. Backlund et al. (2012) argue that successful energy management can increase both the energy efficiency potential and the deployment level of energy policy programs.

Another barrier is that the cost of potential energy savings, typically considered being the only financial benefit, does not sufficiently motivate investments (Popescu et al., 2012). It must be made clear that investments in energy efficiency will add value to buildings and can be paid off within a given time. More studies are required on the calculation of added value due to energy performance. The authors present a method for quantifying the increase in the building value from applying energy efficiency measures. Survey results on the existing Romanian condominiums demonstrated that the transaction prices of the apartments with thermal retrofits were $2-3 \%$ higher than those without retrofits. Popescu et al. (2012) conclude that complete energy audits should be performed to inform the local cost benefits from implementing energy efficiency in buildings, by making it more transparent for practitioners and investors. This might overcome the common problem in some MS, where energy efficiency improvements do not raise the property value or rent (Tuominen et al., 2012).

Challenges and barriers affecting the compliance of the energy efficiency labelling system have been identified, such as cost, information gaps, split incentives, skills shortages and delay in project commencement due to regulatory activities (Rajagopalan and Leung, 2012). Split incentives are common in leased buildings where owners who are responsible for investing capital for building upgrade are different than those who are actually responsible for paying energy bills (i.e. tenants) and can be a challenge to making buildings more energy efficient. For mandatory implementation to take place in Brazil, these economic, technical and political issues must be firstly resolved. Table 6 shows the summary of potential barriers and challenges to the full and mandatory implementation of the existing RTQ-C regulation in Brazil, which can be divided into four primary categories. The summary table is based on the key findings obtained from the literature review and analysis of approximately 100 literature and official reports as well as in-depth studies and comparisons of the calculation methodologies behind RTQ-C and EPBD. Experience and challenges of EPBD implementation reported in official documents, particularly related to RTQ-C and EPBD (EC, 2006; 2013; EU, 2011; 2015; MME, 2009a; 2009b; 2009c; 2009d) have been studied. Based on studies involving literature survey, policy and methodological analysis, relevant information and key findings on potential 
challenges and barriers to RTQ-C implementation, such information was included, pooled and presented in Table 6 .

-Table 6-

4.1 Constraints to the energy performance calculation methodology

There are some constraints in the existing RTQ-C regulation to calculate energy performance of building envelope. For example, only the external envelope of a building is considered in the envelope calculation while ground floor, underground wall, internal walls/ partitions inside the buildings are totally excluded. This may affect the accuracy of the energy performance calculation for building envelope especially in complex commercial buildings. Other factors affecting how energy performance of a building is calculated in RTQ-C regulation are general and specific prerequisites, weighting distribution for building envelope, lighting system and air conditioning system, and types of air conditioning system used (INMETRO certified or not). The actual energy consumed by the air conditioning system however, is not required to be calculated in the existing regulation.

\subsection{Final classification system}

The point (PT) used for scaling system in energy certificate to determine the final classification of a building needs to be revised as there is a lack of explanation on why these points (PT) are used instead of more commonly used indicators such as area-weighted energy consumption (for example, $\mathrm{kWh} / \mathrm{m}^{2}$ ) or carbon emissions which are more consistent and comparable with the international certification schemes.. The award of a bonus point of 1.0 to the use of grey water in the building for example, is particularly less convincing as there is lack of justification on how the point is calculated. Due to tightening of the energy requirements for buildings, re-scaling the labelling of the certificates is also recommended based on the European experience to ensure the scales are valid for a given period of time (EU, 2011).

\subsection{Provision of effective training and support to energy assessors}

There are currently a total of only four AIBs in Brazil for carrying out the RTQ-C assessment. The lack of skilled and capable professionals makes it difficult to ensure compulsory RTQ-C compliance in Brazil, bringing is a major challenge or barrier to its widespread implementation (Tubelo et al., 2013). In order to disseminate the RTQ-C compliance, there is an urgent need to increase the number of AIBs. As discussed by Lamberts et al. (2007) and Tubelo et al. (2013), support and training are needed for energy assessors. It is recommended that a continuous training or re-training programme is established and based on the EU experience, to make it a mandatory requirement for qualified assessors to keep their accreditation. As shown 
by Lopes et al. (2016), Brazil in lagging behind as regards assessment bodies, as the energy efficiency assessments are only issued by AIBs. In the United States and in Portugal, certifications can be issued by professionals responsible for the building assessment. Whereas AIBs may have an interdisciplinary advantage relative to a single specialist, AIBs operate at a much slower pace.

4.4 Provision of cost and energy effective recommendations

It can be learned from the EU experience $(\mathrm{EU}, 2011 ; 2015)$ that the quality and detail of recommendations in energy certificates are an important part of the energy certification process and crucial to the long-term success. The kind of information demonstrated in the certificates should be able to encourage general public to make improvements to their buildings. The recommendations should be on the first pages and contain less technical text. For the recommendations to become effective, the implementation of recommendations should be monitored in order to reshape energy efficiency policies. Under the existing RTQ-C regulation, there is no requirement for any recommendations to be provided for building owners, which can be a challenge to the widespread of the RTQ-C implementation. When comparing the Brazilian rating system with the US and Portugal's rating systems, Lopes et al. (2016) highlighted the need for detailed documentation about improvement measures for the RTQ-C. Those authors report a study carried out in Portugal by the Energy Portuguese Agency that showed that the majority of the occupants who made some renovation or maintenance on their homes actually took into account the improvement suggestions listed on the Portuguese certificate.

4.5 Development of reliable calculation tool for much complex building calculation

Due to the complexity, performing a simulation to determine building energy efficiency label in Brazil can be rather difficult for most practitioners and planers because of the specialized knowledge and expertise required. Until 2011, the simulation method has only been used in less than $5 \%$ of the total energy efficiency labelled buildings in Brazil (Lopes et al., 2011b). The majority of the certificates issued under the existing RTQ-C regulation were calculated using the prescriptive method. From a total of 78 certificates (INMETRO, 2016) issued to date at the building completion stage, there are only 15 certificates issued using simulation method. There is a need to accelerate the development of a reliable simulation tool to generate energy certificates for Brazilian buildings, which is easier to use and user-friendly. Furthermore, improvements in the prescriptive method, as commented before, are underway.

4.6 Cost of certification 
The cost of issuing a certificate largely depends on the calculation method, type and complexity of building, market condition, level of taxes or fees imposed by authorities, and the amount of work necessary for performing and completing expert's tasks in the certification process (EU, 2011). As it can be seen from Table 3, the large variation to the cost of certification for the existing and new buildings makes the actual costs more difficult to determine. There are currently no agreed costs for specific types of buildings, current certification cost for a typical non-residential building in Brazil varies from $\mathrm{R} \$ 10,000$ to $\mathrm{R} \$ 15,000$ (approximately US\$3,000-5,000), depending on the amount of work performed by energy assessors. This certification cost however, is less competitive compared to overall certification cost in the EU due to the limited number of existing AIB available in Brazil. Only with the increasing number of AIB in Brazil, it is anticipate that certification cost can become more competitive. Cost is therefore, an inevitable issue, which would affect the certification on a mass-scale level. The Brazilian government should keep the general certification costs down to make it more affordable, especially for general public and companies or organisations who own large number of buildings. At present, no subsidies, economic or tax incentives are being given in Brazil to energy efficient buildings, but these could be a way of increasing the number of certified buildings (Batista et al., 2011).

\subsection{Increase in education and public awareness}

There is a lack of public awareness regarding the implementation of RTQ-C regulation in Brazil, resulting in the low implementation of RTQ-C. To date, there are only 78 certificates to completion, issued for nonresidential buildings in Brazil, even though the RTQ-C regulation was introduced in 2009 (PROCEL, 2016). Studies show that the general public may not be willing to pay higher rent to live in an energy efficient building or invest more money to build an energy efficient building if they could not understand the benefits of energy efficient buildings (Rodrigues et al., 2012). Education and campaigns are therefore, essential to create awareness of sustainable and energy efficient building designs among general public. One of the common practices adopted in the EU is through mandatory publication of energy certificates in advertisement to sell or rent a property for making the energy performance of the building visible. The mandatory publication of EPC in advertisement can effectively increase the use, relevance and trust of the certificates among buyers (Amecke, 2012). Such obligation can create awareness of energy performance of buildings among potential buyers and tenants, especially if a positive influence of the energy certificates on the real estate market could be monitored and passed on to the market. Widespread dissemination of statistical information from the certification schemes and the relative benefits can lead to a higher degree of acceptance by the general public (EU, 2011). The design of the layout of an energy certificates must be adapted 
according to the needs of the users to make it more user-friendly, which means less technical language and icons are used to make it easier for building owners and general public to understand. Studies show that energy efficient buildings sell or rent faster and at a better price than buildings with lower energy efficiency rating (EU, 2015).

4.8 Effective monitoring and control of certification scheme

A control system is needed to ensure the quality of certificates and calculation method are maintained. It can be used to complement the upstream system, such as, accreditation and expert training (EU, 2011). The provision of support and training to energy assessors should be done under a strict and effective quality assurance (QA) scheme. QA should be performed at various levels such as education and training of assessors, screening of collected data, re-certification and re-scaling, and check or audit on the certification. Effective QA could allow some useful data to be extracted from certificates as an added value such as potential energy savings, benchmarking, determination of policies/ national regulations, and energy consumption profiling for different sectors. Only through enforcing regulations and including sanctions, it would ensure high quality work by assessors and full compliance in the building sector.

\subsection{Effective utilisation of certificate data}

It is recommended to establish a central database for collecting information and data from certificates. As learnt from the European experience, such system not only facilitates quality checks on all certificate data, but enables the accumulation of knowledge about the energy performance of the building stock (EU, 2011). Relevant information gathered from the certificates provides the opportunities for in-depth analyses on energy related topics and discussion and evaluation of the useful data arisen from the certification schemes. Such knowledge could be used effectively to develop national policy documents, improve building regulations/ standards, underpin the base for research on building stock and generate useful statistics on building energy data (EU, 2015).

\section{Conclusions and policy implications}

The success of building energy certification schemes depends on the ability of developing reliable energy certificates cost-effectively and on how accurate the predicted energy consumption data on the certificates can be used to reflect the actual pattern of energy consumption of the buildings (Perez-Lombard et al., 2009). As evidenced in previous literature (Stein and Meier, 2000; Rajagopalan and Leung, 2012), in order to increase the impact of energy certification schemes, an increase in training, education and public awareness, reliable calculation methodology and tools, provision of cost effective recommendations, user-friendly 
certificates and incentives, as well as affordable cost of certification are essential. For energy rating labelling to become successful and effective, users need to be provided with more information on the accuracy of the rating system. A user-friendly certificate, which displays easy-to-understand and less complicated rating system, would be able to help users to interpret energy ratings as most ordinary users have little knowledge on the system (Stein and Meier, 2000). Significant cost and energy savings could be achieved with these supporting measures and also by enforcing energy requirements in building regulations or standards.

Since the publication of the RTQ-C in 2009 , there are only a total of 78 certificates to completion issued in Brazil for commercial or public buildings to date (PROCEL, 2016). Although the RTQ-C regulation has been introduced for seven years, it is still largely at the pre-mature stage for full implementation in the commercial and public building sectors. There has been a lack of momentum and drive for more buildings to be certified at this stage due to various reasons. This study highlighted the difficulties and constraints to the calculation methodology, scope and labelling of the RTQ-C, as well as the areas that require further research, particularly the implications of the RTQ-C implementation on the building sector and potential benefits it could bring to building owners/ occupants. In summary:

- One of the main challenges lying ahead RTQ-C regulations is how to develop methodologies to calculate realistic values which could be used to accurately represent actual building energy performance;

- Campaigns are required to create awareness among general public before the regulation can be fully implemented;

- There is a need for facilitating training and support to increase the number of qualified independent energy assessors or AIBs, which is essential for widespread implementation of RTQ-C in the future;

- To ensure the quality and effectiveness of RTQ-C compliance in Brazil, RTQ-C regulations and rules need to be enforced. The lack of enforcement of RTQ-C regulation results in lack of compliance for a majority of buildings in Brazil. Sanctions in the case of non-compliance are necessary;

- Post-certification monitoring and evaluation measures are essential and have to be part of the certification scheme. It is recommended to establish and maintain a central registration database/system for collecting all relevant data/information from the certificates. The useful data extracted from the certificate database could potentially add value to the building sector, such as energy benchmarking and tightening of the existing regulations. There is a need to develop a consistent approach in assessing the energy savings of the buildings from their energy efficiency measures, in order to verify effectiveness and added value. 
In a policy context, this study helps to inform policy by comparing energy labelling systems in Brazil and the EU/ UK. It contributes to a better understanding of the implementation of energy efficiency systems in Brazil, particularly, by reviewing the issues, challenges and difficulties facing the European countries during the initial implementation (2005 to 2015) of the Directive 2010/31/EU. The experience and lessons from the European countries could be used to inform the development of similar policy in Brazil, particularly, during the transformation from voluntary to compulsory. As the implementation of the Directive 2010/31/EU in the EU has witnessed the reduction of building energy consumption of up to $60 \%$ in MS through enforcing the regulations, it is anticipated that through the full implementation of the RTQ-C regulation in Brazil, the energy consumption in the Brazilian building sector could potentially be reduced significantly in the long term.

\section{Acknowledgements}

This work was supported by Conselho Nacional das Fundações Estaduais de Amparo à Pesquisa (CONFAP), Brazil in partnership with the UK Academies under Newton Fund (CONFAP-UK Academies Call 2015). The authors also would like to thank Professor Roberto Lamberts (Federal University of Santa Catarina, Brazil), Fabiano Kiyoshi Mori (Caixa Econômica Federal, Brazil) and Ana Claudia Menoncin Loper for discussions on the topic.

\section{References}

ABNT, 2013a. NBR 15575-4_2013 Edificações habitacionais - Desempenho Parte 4: Sistemas de vedações verticais internas e externas - SVVIE (In Portuguese).

ABNT, 2013b. NBR 15575-5_2013 Edificações habitacionais - Desempenho Parte 5: Requisitos para sistemas de coberturas (In Portuguese).

Allcott, H., Greenstone, M., 2012. Is There an Energy Efficiency Gap? Journal of Economic Perspectives. 26(1), 3-28.

Allouhi, A., El Fouih, Y., Kousksou, T., Jamil, A., Zeraouli, Y., Mourad, Y., 2015. Energy consumption and efficiency in buildings: current status and future trends. Journal of Cleaner Production. 109, 118-130.

Andaloro, A. P., Salomone, R., Ioppolo, G., \& Andaloro, L., 2010. Energy certification of buildings: A comparative analysis of progress towards implementation in European countries. Energy Policy. 38(10), 5840-5866.

Amecke, H., 2012. The impact of energy performance certificates: A survey of German home owners. Energy Policy. 46, 4-14.

Annunziata, E., Frey, M., \& Rizzi, F., 2013. Towards nearly zero-energy buildings: The state-of-art of national regulations in Europe. Energy. 57, 125-133.

Australian Bureau of Statistics, 2008. Energy efficiency rating and house prices in the ACT. Report for Department of the Environment, Water, Heritage and Arts.

Backlund, S., Thollander, P., Palm, J., Ottosson, M., 2012. Extending the energy efficiency gap. Energy Policy. 51, 392-396. 
Bannister, P., 2013. NABERS: Lessons from 12 Years of Performance Based Ratings in Australia. Energy Systems Laboratory (http://esl.tamu.edu); Texas A\&M University (http://www.tamu.edu). Available electronically from http : / /hdl .handle .net/1969.1/148920.

Batista, N.d.N., La Rovere, E.L., Aguiar, J.C.R., 2011. Energy efficiency labelling of buildings: An assessment of Brazilian case. Energy and Buildings. 43, 1179-1188

Borgstein, E.H., Lamberts, R., 2014. Developing energy consumption benchmarks for buildings: Bank branches in Brazil. Energy and Buildings. 82, 82-91.

Borgstein, E.H., Lamberts, R., Hensen, J.L.M., 2016. Evaluating energy performance in non-domestic buildings: A review. Energy and Buildings. 128, 734-755.

Brandalise, M.P., Grala da Cunha, E., Cristina de Oliveira, L., 2016. Sensibility Analysis of the Brazilian Standards for Energy Efficiency Regarding the Variation of Internal Load Density in Office Buildings in Brazilian Bioclimatic Zones 1 and 7. Journal of Civil Engineering and Architecture. 10, 22-36.

Brounen, D., Kok, N., 2011. On the economics of energy labels in the housing market. Journal of Environmental Economics and Management. 62(2), 166-179.

Cajias, M., Piazolo, D., 2013. Green performs better: energy efficiency and financial return on buildings. Journal of Corporate Real Estate. 15(1), 53-72.

Campos, I.B., Neto, J.d.P.B., 2012. Análise da adequação de um edifício comercial à etiqueta PROCEL edifica de eficiência energética (in Portuguese). XIV ENTAC - Encontro Nacional de Tecnologia do Ambiente Construído, Juiz de Fora, Brazil. 29-31 October, 2718-2726.

Carlo, J., Lamberts, R., 2008. Development of envelope efficiency labels for commercial buildings: Effect of different variables on electricity consumption. Energy and Buildings. 40, 2002-2008.

Carlo, J., Lamberts, R., 2010. Parameters and methods adopted in the energy eficiency regulation for buildings - part 1: prescriptive method. Ambiente Construído, Porto Alegre. 10 (2), 7-26.

Casals, X.G., 2006. Analysis of building energy regulation and certification in Europe: Their role, limitations and differences. Energy and Buildings. 38, 381-392.

Chai, K.H., Yeo, C., 2012. Overcoming energy efficiency barriers through systems approach - A conceptual framework. Energy Policy. 46, 460-472.

Curtis, J., Pentecost, A., 2015. Household fuel expenditure and residential building energy efficiency ratings in Ireland. Energy Policy. 76, 57-65.

De Oliveira, L.S., Shayani, R.A., De Oliveira, M.A.G., 2013. Proposed business plan for energy efficiency in Brazil. Energy Policy. 61, 523-531.

Department of Communities and Local Government, 2008. The Government's methodology for the production of operational ratings, display energy certificates and advisory reports. Communities and Local Government Publications, Wetherby. ISBN: 978-1-4098-04178.

Department of Energy, U.S., 2012. Buildings Energy Data Book, Table 1.1.3. (Available at: http://buildingsdatabook.eren.doe.gov/docs/xls_pdf/1.1.3.pdf).

Diário Oficial da República Federativa do Brasil, 2001a. Lei No. 10.295, de 17de outubro de 2001. Dispõe sobre a Política Nacional de Conservac, ão e UsoRacional de Energia e dá outras providências, Diário Oficial da República Federativa do Brasil, Brasília (Rules on the National Energy Conservation and Rational Use of Energy) (in Portuguese).

Diário Oficial da República Federativa do Brasil, 2001b. Decreto No. 4.059, de 19de dezembro de, 2001. Regulamenta a Lei No. 10.295 e dá outras providências, Diário Oficial da República Federativa do Brasil, Brasília (Code-Decree 4.059) (in Portuguese).

Dinan, T.M., Miranowski, J.A., 1989. Estimating the implicit price of energy efficiency improvements in the residential housing market: A hedonic approach. Journal of Urban Economics. 25(1), 52-67.

Eichholtz, P., Kok, N., Quigley, J.M., 2009. Doing good by doing well? Green office buildings. Institute of Business and Economic Research, University of California, Berkeley, Working paper W008-001; January 2009. (Available at: http://www.ucei.berkeley.edu/PDF/seminar20090130.pdf ).

EMPRESA, DE PESQUISA ENERGÉTICA - EPE, 2015. Anuário estatístico de energia elétrica. Brasília: Empresa de Pesquisa Energética. EMPRESA, DE PESQUISA ENERGÉTICA-EPE.

Energy World, 2017. Why is Australia better than the UK at building energy efficiency? 18-20. 
European Council, 1993. Directive 93/76/EEC to Limit Carbon Dioxide Emissions by Improving Energy Efficiency (SAVE).

European Council, 2002. Directive 2002/91/EC of the European Parliament and of the Council of 16 December 2002 on the energy performance of buildings (EPBD).

European Council, 2010. Directive 2010/31/EU of the European Parliament and of the Council of 19 May 2010 on the energy performance of buildings (recast) (EPBD recast).

European Commission, 2011. A roadmap for moving to a competitive low carbon economy in 2050. Communication from the Commission to the European Parliament, the Council, the European Economic and Social Committee and the Committee of the Regions (Available at: http://eurlex.europa.eu/LexUriServ/LexUriServ.do?uri=COM:2011:0112:FIN:EN:PDF).

European Commission, 2012. Directive 2012/27/EC of the European Parliament and of the Council of 25 October 2012 on energy efficiency, amending Directives 2009/125/EC and 2010/30/EU and repealing Directives 2004/8/EC and 2006/32/EC Text with EEA relevance.

European Commission, 2013. Energy performance certificates in buildings and their impact on transaction prices and rents in selected EU countries. Final Report. European Commission (DG Energy) 19 April 2013.

European Communities, 2006. Energy Performance of Buildings Regulations 2006, S.I. No. 666 of 2006. The Stationary Office, Dublin.

European Union, 2011. Implementing the Energy Performance of Building Directive (EPBD), Featuring country reports 2010. Brussels. ISBN 978-92-9202-090-3.

European Union, 2015. Implementing the Energy Performance of Building Directive (EPBD), Featuring country reports 2016. Lisbon. ISBN 978-972-8646-32-5.

Fabbri, K., Tronchin, L., Tarabusi, V., 2011. Real Estate market, energy rating and cost. Reflections about an Italian case study. Procedia Engineering. 21, 303-310.

Fernandes, L.O. Labaki, L.C., 2012. The influence of the shading of surroundings on the Brazilian labelling of building energy efficiency. In: Proceeding of PLEA2012 - $28^{\text {th }}$ Conference, Opportunities, Limits \& Needs Towards an environmentally responsible architecture. Lima, Perú, 7-9 November.

Fossati, M., Lamberts, R., 2010. Energy efficiency of office buildings envelope: discussions around application of prescriptive method of RTQ-C. Ambiente Construído, Porto Alegre. 10 (2), 59-69 (In Portuguese).

Fossati, M., Scalco, V.A., Linczuk, V.C.C., Lamberts, R., 2016. Building energy efficiency: An overview of the Brazilian residential labeling scheme. Renewable and Sustainable Energy Reviews. 65, 1216-1231.

Fuerst, F., McAllister, P., 2011. The impact of energy performance certificates on the rental and capital values of commercial property assets. Energy Policy. 39, 6608-6614.

Fuerst, F., McAllister, P., Nanda, A., Wyatt, P., 2015. Does energy efficiency matter to home-buyers? An investigation of EPC ratings and transaction prices in England. Energy Economics. 48, 145-156.

Fuerst, F., McAllister, P., Nanda, A., Wyatt, P., 2016. Energy performance ratings and house prices in Wales: An empirical study. Energy Policy. 92, 20-33.

Gillingham, K., Palmer, K., 2014. Bridging the energy efficiency gap: Policy insights from economic theory and empirical evidence. Review of Environmental Economics and Policy. 8(1), 18-38.

Gilmer, R.W., 1989. Energy labels and economic search: an example from the residential real estate market. Energy Economics. 11(3), 213-218.

Harrington, L., Damnics, M., (2004. Energy labelling and standards programs throughout the world. The National Appliance and Equipment Energy Efficiency Committee Report, Australia.

Hernandez, P., Burke, K., Lewis, J.O., 2008. Development of energy performance benchmarks and building energy ratings for non-domestic buildings: An example for Irish primary schools. Energy and Buildings. 40, 249-254.

Hyland, M., Lyons, R.C., Lyons, S., 2013. The value of domestic building energy efficiency - evidence from Ireland. Energy Economics. 40, 943-952.

Inmetro, 2016. Instituto Nacional de Metrologia, Qualidade e Tecnologia (Brazilian National Institute of Metrology, Quality and Technology). TABELA DE EDIFICAÇÕES COMERCIAIS, DE SERVIÇOS E PÚBLICOS (In Portuguese). Accessible: http://www.inmetro.gov.br/consumidor/pbe/tabelas-comerciais.pdf (accessed on $7^{\text {th }}$ October 2016). 
Inmetro, 2017. Instituto Nacional de Metrologia, Qualidade e Tecnologia (Brazilian National Institute of Metrology, Quality and Technology). Organismos Acreditados (Accredited Inspection Bodies). (In Portuguese). Accessible: http://www.inmetro.gov.br/organismos/consulta.asp (accessed on $9^{\text {th }}$ June 2017).

Jaffe, A. B., Stavins, R. N., 1994. The energy-efficiency gap: What does it mean? Energy policy. 22(10), 804-810.

Janda, K., 2009. Worldwide status of energy standards for buildings: a 2009 update. ECEEE 2009 Summer Study, ACT! Innovative! Deliver! Reducing Energy Demand Sustainably. 485-491.

Jensen, O.M., Hansen, A.R., Kragh, J., 2016. Market response to the public display of energy performance rating at property sales. Energy Policy. 93, 229-235.

Kahn, M.E., Kok, N., 2012. The value of green labels in the Californian housing market. (Available at: http://www.corporate-engagement.com/files/publication/KK_Green_Homes_071912.pdf).

Klejsgård Hansen, A., 2011. Holdningsskred - Energimærket afgørboligkøb (Change of Attitude - Energy Label Determines Purchasing of Houses). Bolius 4/2011, 12-16.

Kok, N., Jennen, M., 2012. The impact of energy labels and accessibility on office rents. Energy Policy. 46, 489-497.

Kramer, R., van Schijndel, J., Schellen, H., 2012. Simplified thermal and hygric building models: a literature review. Frontiers of Architectural Research. 1(4), 318-325.

Lamberts, R., 1996. Electricity efficiency in commercial and public buildings. Energy for Sustainable Development. 2 (6), 49-52.

Lamberts, R., Goulart, S., Carlo, J., Westphal, F., 2006. Regulation proposal for voluntary energy efficiency labelling of commercial buildings. Proceedings of ENCIT 2006, ABCM, Curitiba, Brazil, 5-8 December, 2006, Paper CIT06-0104 (In Portuguese).

Lamberts, R., Goulart, S., Carlo, J., Westphal, F., 2007. Regulation for energy efficiency labelling of commercial buildings in Brazil. Proceedings of $2^{\text {nd }}$ PALENC Conference and $28^{\text {th }}$ AIVC Conference on Building Low Energy Cooling and Advanced Ventilation Technologies in the $21^{\text {st }}$ Century, Crete island, Greece, 27-29 September, 602-609.

Lopes, A.d.C.P., Filho, D.O., Altoe, L., Carlo, J.C., Lima, B.B., 2016. Energy efficiency labelling program for buildings in Brazil compared to the United States' and Portugal's. Renewable and Sustainable Energy Reviews. 66, 207-219.

Lopes, M.N., Iwamoto, G., Riella, H.L., Lamberts, R., Campos, L.M.S., 2011a. The building simulation as an alternative method in Brazilian energy efficiency labelling of commercial buildings. Proceedings of Building Simulation 2011: $12^{\text {th }}$ Conference of International Building Performance Simulation Association, Sydney, 14-16 November, 2055-2062.

Lopes, M.N., Iwamoto, G., Riella, H.L., Lamberts, R., Campos, L.M.S., 2011b. Development of computational tool to evaluate the building energy efficiency level according to the Brazilian labelling. Proceedings of Building Simulation 2011: $12^{\text {th }}$ Conference of International Building Performance Simulation Association, Sydney, 14-16 November, 2040-2047.

Meier, A., Olofsson, T., Lamberts, R., 2002. What is an energy-efficient building? IX Encontro Nacional de Tecnologia do Ambiente Construido, Foz do Iguaçu, Brazil, 7-10 May, 3-12.

Melo, A.P., Lamberts, R., Costola, D., Hensen, J.L.M., 2011. Capability and deficiency of the simplified model for energy calculation of commercial buildings in the Brazilian regulation. In: Proceeding of the $12^{\text {th }}$ International IBPSA conference, Sydney, 14-16 November, 902-909.

Melo, A.P., Costola, D., Lamberts, R., Hensen, J.L.M., 2012. Assessing the accuracy of a simplified building energy simulation model using BESTEST: The case study of Brazilian regulation. Energy and Buildings. 45, 219-228.

Melo, A.P., Lamberts, R., Costola, D., Hensen, J.L.M., 2013. Development of a method to predict building energy consumption through an artificial neural network approach. Proceedings of BS2013: 13th Conference of International Building Performance Simulation Association, Chambéry, France, August 26-28, 644-651.

Melo, A.P., Sorgato, M.J., Lamberts, R., 2014. Building energy performance assessment: Comparison between ASHRAE standard 90.1 and Brazilian regulation. Energy and Buildings. 70, 372-383.

Melo, A.P., Fossati, M., Versage, R.S., Sorgato, M.J., Scalco, V.A., Lamberts, R., 2016. Development and analysis of a metamodel to represent the thermal behavior of naturally ventilated and artificially airconditioned residential buildings. Energy and Buildings. 112, 209-221. 
Miguez, J.L., Porteiro, J., Lopez-Gonzalez, L.M., Vicuna, J.E., Murillo, S., Moran, J.C., Granada, E., 2006. Review of the energy rating of dwellings in the European Union as a mechanism for sustainable energy. Renewable and Sustainable Energy Reviews. 10, 24-45.

Ministry of Mines and Energy (MME), 2009a. 1 - Etiquetagem de Eficiência Energética de Edificações (in Portuguese).

Ministry of Mines and Energy (MME), 2009b. 2 - Regulamento Técnico da Qualidade do Nível de Eficiência Energética de Edifícios Comerciais, de Servicos e Públicos (in Portuguese).

Ministry of Mines and Energy (MME), 2009c. 3 - Requisitos de Avaliação da Conformidade para o Nível de Eficiência Energética de Edifícios Comerciais, de Serviços e Públicos (in Portuguese).

Ministry of Mines and Energy (MME), 2009d. 4 - Manual de Aplicação dos Regulamentos: RTQ-C e RAC-C (in Portuguese).

Ministry of Mines and Energy (MME), 2015. Brazilian Energy Balance 2015: Year 2014. Empresa de Pesquisa Energética, Rio de Janeiro, Brasil.

Nogueira, L.A.H., Cardoso, R.B., Cavalcanti, C.Z.B., Leonelli, P.A., 2015. Evaluation of the energy impacts of the Energy Efficiency Law in Brazil. Energy for Sustainable Development. 24, 58-69.

Olofsson, T., Meier, A., Lamberts, R., 2004. Rating the Energy Performance of Buildings. The International Journal of Low Energy and Sustainable Buildings. 3.

Perez-Lombard, L., Ortiz, J., Gonzalez, R., Maestre, I.R., 2009. A review of benchmarking, rating and labelling concepts within the framework of building energy certification schemes. Energy and Buildings. 41, 272-278.

Piai, J.C., de Oliveira Sfeir, B., Ribeiro, C.H., Larini, M.M., Modesto, A.L.N., de Martino Jannuzzi, G., 2015. Energy efficient diagnostic of the lighting system in a Pulic Building - a simulation example. ESPAÇO ENERGIA. 23, 26-34 (in Portuguese).

Pollis, H., 2013. Climate change and energy efficiency, CLIM0001: EE and Climates Changes integration actions in Brazil. DIÁLOGOS SETORIAIS UNIÃO EUROPEIA - BRASIL, May 2013.

Popescu, D., Bienert, S., Schutzenhofer, C., Boazu, R., 2012. Impact of energy efficiency measures on the economic value of buildings. Applied Energy. 89, 454-463.

Rackes, A., Melo, A.P., Lamberts, R., 2016. Naturally comfortable and sustainable: Informed design guidance and performance labeling for passive commercial buildings in hot climates. Applied Energy. 174, 256-274.

Rajagopalan, P., Leung, T.C.Y., 2012. Progress on building energy labelling techniques. Advances in Building Energy Research. 6(1), 61-80.

Rosen, S., 1974. Hedonic prices and explicit markets: production differentiation in pure competition. Journal of Political Economy. 82, 34-55.

Ryan, L., Campbell, N., 2012. Spreading the net: the multiple benefits of energy efficiency improvements, $2^{\text {nd }}$ edition. International Energy Agency, France.

Santos, P., Wittchen, K.B., 2011. The price of energy performance certificates. Concerted Action: Energy Performance of Buildings.

Scalco, V.A., Fossati, M., Versage, R.d.S., Sorgato, M.J., Lamberts, R., Morishita, C., 2012. Innovation in the Brazilian regulations for energy efficiency of residential buildings. Architectural Science Review. 55 (1), 71-81.

Stead, N., 2009. Green Stars and a little iceberg - Terror refurbish the SHFA's heritage-listed building and make a new public space. Architecture Australia. 98(3), 77-82.

Stein, J.R., Meier, A., 2000. Accuracy of home energy rating systems. Energy. 25, 339-354.

Strong, D., 2009. EU Energy Performance of Buildings Directive: The writing on the wall. Building, 14 August 2009. Available at http://www.building.co.uk/technical/sustainability/eu-energy-performance-ofbuildings-directive-the-writing-on-the-wall/3146849.article.

Tubelo, R.C.S., Rodrigues, L., Gillott, M., 2013. A Parallel between the Brazilian Energy Labelling System and the Passivhaus Standard for Housing. Proceedings of PLEA2013 - $29^{\text {th }}$ Conference, Sustainable Architecture for a Renewable Future, Munich, Germany 10-12 September 2013. 
Tuominen, P., Klobut, K., Tolman, A., Adjei, A., de Best-Waldhober, M., 2012. Energy savings potential in buildings and overcoming market barriers in member states of the European Union. Energy and Buildings. 51, 48-55.

Van der Knaap, A.N., 2011. Building performance simulation to support building energy regulation: A case study for residential buildings in Brazil. Thesis, Master Building Services, Department of the Built Environment, Eindhoven University of Technology.

Wong, P.S.P., Lindsay, A., Crameri, L., Holdsworth, S., 2015. Can energy efficiency rating and carbon accounting foster greener building design decision? An empirical study. Building and Environment. 87, 255264.

Zmeureanu, R., Fazio, P., DePani, S., Calla, R., 1999. Development of an energy rating system for existing houses. Energy and Buildings. 29, 107-119. 